\title{
COMPOSITION AND Th - U - TOTAL Pb AGES OF HUTTONITE AND THORITE FROM GILLESPIE'S BEACH, SOUTH ISLAND, NEW ZEALAND
}

\author{
HANS-JÜRGEN FÖRSTER ${ }^{\S}$, DANIEL E. HARLOV AND RALF MILKE \\ GeoForschungsZentrum Potsdam, Telegrafenberg, D-14473 Potsdam, Germany
}

\begin{abstract}
The average result of 49 electron-microprobe spot analyses of huttonite (monoclinic $\mathrm{ThSiO}_{4}$ ) from its type locality, Gillespie's Beach, southern Westland, New Zealand, yields the following chemical composition (in wt. $\%, \pm 1 \sigma$ standard deviation in italics in parentheses): $\mathrm{P}_{2} \mathrm{O}_{5} 0.43(0.13), \mathrm{SiO}_{2} 18.78(0.17), \mathrm{ThO}_{2} 79.21(0.53), \mathrm{UO}_{2} 0.66(0.07), \mathrm{Y}_{2} \mathrm{O}_{3} 0.35(0.15), \mathrm{La}_{2} \mathrm{O}_{3} 0.02(0.02)$, $\mathrm{Ce}_{2} \mathrm{O}_{3} 0.06$ (0.07), $\mathrm{Pr}_{2} \mathrm{O}_{3} 0.02$ (0.02), $\mathrm{Nd}_{2} \mathrm{O}_{3} 0.12$ (0.08), $\mathrm{Sm}_{2} \mathrm{O}_{3} 0.06$ (0.05), $\mathrm{Gd}_{2} \mathrm{O}_{3} 0.10(0.05), \mathrm{Dy}_{2} \mathrm{O}_{3} 0.06(0.04), \mathrm{CaO} 0.01$ $(0.01), \mathrm{FeO} 0.01(0.01), \mathrm{PbO} 0.03(0.01)$, total $99.94(0.32)$. Huttonite is very close to the theoretical ideal stoichiometry, with the general formula $\left(\mathrm{Th}_{0.96} \mathrm{U}_{0.01} \mathrm{Y}_{0.01} R E E_{0.01}\right)_{\Sigma 0.99}\left(\mathrm{Si}_{0.99} \mathrm{P}_{0.02}\right)_{\Sigma 1.01} \mathrm{O}_{4}$. It displays little compositional heterogeneity and is near endmember composition (93.2 to $98.4 \mathrm{~mol} \% \mathrm{ThSiO}_{4}$ ). The chondrite-normalized $R E E$ patterns are umbrella-like, with Gd being the most prominent rare-earth element. The $\mathrm{P}, \mathrm{U}, \mathrm{Fe}$, and total $R E E$ contents of the grains studied differ strongly from those of the type material published by Pabst \& Hutton (1951). Thorite (tetragonal $\mathrm{ThSiO}_{4}$ ) from Gillespie's Beach displays the following average composition $(n=30): \mathrm{P}_{2} \mathrm{O}_{5} 0.12(0.09), \mathrm{SiO}_{2} 18.84(0.18), \mathrm{ThO}_{2} 73.46(1.85), \mathrm{UO}_{2} 5.90(1.46), \mathrm{Y}_{2} \mathrm{O}_{3} 0.21(0.11), \mathrm{La}_{2} \mathrm{O}_{3}$ 0.00 (0.01), $\mathrm{Ce}_{2} \mathrm{O}_{3} 0.08$ (0.05), $\mathrm{Pr}_{2} \mathrm{O}_{3} 0.02$ (0.04), $\mathrm{Nd}_{2} \mathrm{O}_{3} 0.07$ (0.05), $\mathrm{Sm}_{2} \mathrm{O}_{3} 0.04(0.04), \mathrm{Gd}_{2} \mathrm{O}_{3} 0.04(0.04), \mathrm{Dy}_{2} \mathrm{O}_{3} 0.04(0.04)$, $\mathrm{CaO} 0.13(0.08), \mathrm{PbO} 0.43(0.20)$, total $99.42(0.44)$. Like huttonite, it is virtually non-metamict, nearly stoichiometric $\left[\left(\mathrm{Th}_{0.90} \mathrm{U}_{0.07} \mathrm{Y}+R E E_{0.01} \mathrm{Ca}_{0.01} \mathrm{~Pb}_{0.01}\right)_{\Sigma 1.00} \mathrm{Si}_{1.01} \mathrm{O}_{4}\right]$ and approaches end-member composition $(86.3$ to $96.7 \mathrm{~mol} . \% \mathrm{ThSiO}$ ). $\mathrm{Th}-\mathrm{U}$ - total $\mathrm{Pb}$ dating reveals a late Tertiary (Miocene) age for the huttonite. The thorite records older ages, from late Triassic-early Jurassic to early Tertiary. All ages coincide with major metamorphic or magmatic events on South Island. Rocks that formed in the experimentally derived P-T stability field of huttonite are unknown in the area. There thus are suggestions of discrepancies between the experimental data on huttonite-thorite phase relations and those observed in natural systems.
\end{abstract}

Keywords: huttonite, thorite, electron-microprobe analysis, Th - U - total $\mathrm{Pb}$ age, regional geology, Gillespie's Beach, South Island, New Zealand.

\section{SOMMAIRE}

La composition moyenne de la huttonite $\left(\mathrm{ThSiO}_{4}\right.$ monoclinique), déterminée à partir de 49 analyses ponctuelles à la microsonde électronique d'échantillons de la localité-type, Gillespie's Beach, Westland du sud, en Nouvelle-Zélande, est comme suit (en \% pondéraux, $\pm 1 \sigma$ écart-type en italiques entre parenthèses): $\mathrm{P}_{2} \mathrm{O}_{5} 0.43(0.13), \mathrm{SiO}_{2} 18.78(0.17), \mathrm{ThO}_{2} 79.21(0.53)$, $\mathrm{UO}_{2} 0.66(0.07), \mathrm{Y}_{2} \mathrm{O}_{3} 0.35(0.15), \mathrm{La}_{2} \mathrm{O}_{3} 0.02$ (0.02), $\mathrm{Ce}_{2} \mathrm{O}_{3} 0.06(0.07), \mathrm{Pr}_{2} \mathrm{O}_{3} 0.02(0.02), \mathrm{Nd}_{2} \mathrm{O}_{3} 0.12(0.08), \mathrm{Sm}_{2} \mathrm{O}_{3} 0.06$ (0.05), $\mathrm{Gd}_{2} \mathrm{O}_{3} 0.10$ (0.05), $\mathrm{Dy}_{2} \mathrm{O}_{3} 0.06$ (0.04), $\mathrm{CaO} 0.01$ (0.01), FeO 0.01 (0.01), PbO 0.03 (0.01), total 99.94 (0.32). Cette composition se rapproche de très près de la stoechiométrie idéale: $\left(\mathrm{Th}_{0.96} \mathrm{U}_{0.01} \mathrm{Y}_{0.01} R E E_{0.01}\right)_{\Sigma 0.99}\left(\mathrm{Si}_{0.99} \mathrm{P}_{0.02}\right)_{\Sigma 1.01} \mathrm{O}_{4}$. Les cristaux sont assez homogènes et se rapprochent du pôle (de 93.2 à $98.4 \% \mathrm{ThSiO}_{4}$ en termes molaires). Les spectres de terres rares, normalisés par rapport à une chondrite, ont l'allure d'un parapluie, le Gd étant la terre rare la plus concentrée. Les teneurs en $\mathrm{P}$, $\mathrm{U}, \mathrm{Fe}$, et terres rares totales des grains étudiés diffèrent de façon marquée des teneurs établies dans la description originelle de Pabst et Hutton (1951). La thorite $\left(\mathrm{ThSiO}_{4}\right.$ tétragonal) provenant de Gillespie's Beach possède la composition moyenne suivante $(n=30): \mathrm{P}_{2} \mathrm{O}_{5} 0.12$ (0.09), $\mathrm{SiO}_{2} 18.84(0.18), \mathrm{ThO}_{2} 73.46$ (1.85), $\mathrm{UO}_{2} 5.90(1.46), \mathrm{Y}_{2} \mathrm{O}_{3} 0.21(0.11), \mathrm{La}_{2} \mathrm{O}_{3} 0.00(0.01), \mathrm{Ce}_{2} \mathrm{O}_{3}$ 0.08 (0.05), $\mathrm{Pr}_{2} \mathrm{O}_{3} 0.02$ (0.04), $\mathrm{Nd}_{2} \mathrm{O}_{3} 0.07$ (0.05), $\mathrm{Sm}_{2} \mathrm{O}_{3} 0.04$ (0.04), $\mathrm{Gd}_{2} \mathrm{O}_{3} 0.04(0.04), \mathrm{Dy}_{2} \mathrm{O}_{3} 0.04(0.04), \mathrm{CaO} 0.13(0.08)$, $\mathrm{PbO} 0.43(0.20)$, total $99.42(0.44)$. Tout comme la huttonite, la thorite est quasiment non métamicte et presque stoechiométrique $\left[\left(\mathrm{Th}_{0.90} \mathrm{U}_{0.07} \mathrm{Y}+R E E_{0.01} \mathrm{Ca}_{0.01} \mathrm{~Pb}_{0.01}\right)_{\Sigma 1.00} \mathrm{Si}_{1.01} \mathrm{O}_{4}\right]$, et elle aussi s'approche du pôle (de $\left.86.3 \mathrm{à} 96.7 \% \mathrm{ThSiO}_{4}\right)$. Une datation fondée sur les teneurs en $\mathrm{Th}, \mathrm{U}$ et $\mathrm{Pb}$ total révèle un âge tertiaire tardif (miocène) de formation de la huttonite. En revanche, la thorite indique un âge de formation plus ancien, allant de triassique tardif ou jurassique précoce à tertiaire précoce. Tous les âges coïncident avec des événements métamorphiques ou magmatiques majeurs à South Island. On ne connait pas de roches qui ont été formées dans des conditions P-T qui correspondent au champ de stabilité de la huttonite, telles qu'établies par expériences. Les relations de phases entre thorite et huttonite déduites à partir des études expérimentales ne concordent pas bien avec les observations de terrain.

(Traduit par la Rédaction)

Mots-clés: huttonite, thorite, analyses à la microsonde électronique, âge $\mathrm{Th}-\mathrm{U}$ - Pb total, géologie régionale, Gillespie's Beach, South Island, Nouvelle-Zélande.

§ E-mail address: forhj@gfz-potsdam.de 


\section{INTRODUCTION}

The monazite group of minerals, of monoclinic symmetry, is composed of three end-members: monazite, brabantite, and huttonite (e.g., Förster 1998). Huttonite $\left(\mathrm{ThSiO}_{4}\right)$ has a tetragonal dimorph, thorite. The experimentally defined thorite-huttonite phase transition at 1 atm is located between 1210 and $1225^{\circ} \mathrm{C}$ (Finch et al. 1964, Seydoux \& Montel 1997). However, at high pressures, huttonite apparently is stable over a range of temperatures (Dachille \& Roy 1964). Its restricted field of stability at pressures and temperatures normally encountered in the Earth's crust is thought to account for the rarity of huttonite relative to thorite in nature (Speer 1982). The two minerals can be distinguished only by their X-ray-diffraction patterns (Pabst \& Hutton 1951).

To date, huttonite is known from three localities: 1) its type-locality, Gillespie's Beach, southern Westland, South Island, New Zealand (Pabst \& Hutton 1951), where it is found as minute grains of composition $\mathrm{Htn}_{89.1}$ in the beach sands, 2) granitic pegmatites from Bogatynia, Poland (Kucha 1980), where the huttonite component approaches $66 \mathrm{~mol} . \%$, and 3) nepheline syenite from Brevik, Norway (Meldrum et al. 1999; no compositional data reported). Further unconfirmed occurrences include (1) granitic pegmatites in the Santa Maria de Itabira pegmatite district, Minas Gerais, Brazil (Bilal et al. 1998), (2) the Lovozero alkaline complex, Kola Peninsula, Russia (Chakhmouradian \& Sitnikova 1999), (3) the S-type, peraluminous Tribeč granodiorite in Slovakia (Broska et al. 2000), and (4) the Holliday mine in Mineral County, Nevada, U.S.A. (G.W. Robinson, pers. commun., 2000). However, to our knowledge, the huttonite from all these occurrences has not been confirmed by X-ray analysis because of its small grain-size. In addition, only about one dozen occurrences of members of the monazite-huttonite series that contain between 25 and $50 \mathrm{~mol} . \% \mathrm{ThSiO}_{4}$ have been described [see Förster \& Harlov (1999) for a compilation].

The physical and optical properties of huttonite from Gillespie's Beach as well as its occurrence and mineral assemblage have been described in detail by Pabst \& Hutton (1951). Its chemical composition was determined by wet-chemical techniques using purified mineral separates. However, the authors (Table 1) did not distinguish among the individual rare-earth elements (REEs) beyond giving analytical data for $\mathrm{Ce}_{2} \mathrm{O}_{3}$ and "others". Moreover, calculation of molar proportions from the average composition published by Pabst \& Hutton (1951) reveals a deviation from theoretical stoichiometry (sum of cations $=8.163$; cations calculated on the basis of 16 atoms of oxygen).

In connection with an ongoing study of thorite (H.-J. Förster, in prep.), we realized that recent knowledge on the composition of huttonite was insufficient to permit detailed comparison between the two Th minerals. Attempts to obtain access to type-huttonite from the origi- nal sample described by Pabst \& Hutton (1951) for electron-microprobe re-examination failed. However, the Smithsonian Institute kindly provided a number of huttonite grains separated from another sample of beach sand from Gillespie's Beach. From these, three grains were successfully mounted for electron-microprobe analysis in order to determine, in particular, the entire spectrum of REEs. In addition, in heavy-mineral fractions of beach-sand samples from the huttonite type-locality and nearby Bruce Bay, U-bearing thorite was identified. Since uranothorite had also been mentioned by Pabst \& Hutton (1951) as part of the huttonite assemblage, it was decided that it might be profitable to examine the composition of the dimorph of huttonite more carefully. Given their apparent non-metamict state, both $\mathrm{ThSiO}_{4}$ dimorphs were used to calculate $\mathrm{U}-\mathrm{Th}-$ total $\mathrm{Pb}$ ages, which are compared with the ages of major metamorphic and magmatic events on South Island.

\section{Analytical Procedures}

\section{Electron-micropobe examination}

Analyses of the Th silicates were done using the CAMEBAX SX-50 electron microprobe, employing a PAP correction procedure (Pouchou \& Pichoir 1985). The operating conditions were: accelerating potential 20 $\mathrm{kV}$, beam current $50 \mathrm{nA}$ (measured on the Faraday cup), and beam diameter $1 \mu \mathrm{m}$. The counting times on the peak were $300 \mathrm{~s}$ for $\mathrm{Pb}, 200 \mathrm{~s}$ for $\mathrm{U}$, and $60 \mathrm{~s}$ for $\mathrm{Th}$ and, in each case, half that time for background counts on both sides of the peak. For the REE and other elements, counting times were $80 \mathrm{~s}$ on the peak.

$\mathrm{X}$-ray lines and background offsets were selected to minimize interferences and their correction (Exley 1980, Roeder 1985). Wavelength-dispersion spectral scans done on complex natural REE phosphates (monazite and xenotime) were used to determine the peak and background positions of each element and to identify overlapping peaks. $K \alpha$ lines were used for $\mathrm{P}, \mathrm{Si}, \mathrm{Fe}$, and $\mathrm{Ca}$; $L \alpha$ lines for $\mathrm{Y}, \mathrm{La}$, and $\mathrm{Ce}$, and $L \beta$ lines for $\mathrm{Pr}, \mathrm{Nd}, \mathrm{Sm}$, $\mathrm{Gd}$, and Dy. The interferences of ThM $\beta$ on $\mathrm{U} M \alpha$ and of $\mathrm{Y} L \alpha$ on $\mathrm{Pb} M \alpha$ were eliminated by using the $\mathrm{Th} M \alpha$, $\mathrm{U} M \beta$ and $\mathrm{Pb} M \beta$ lines. Minor interferences of ThM on $\mathrm{U} M \beta$ were corrected using the procedure of Åmli \& Griffin (1975).

Primary standards included pure metals for Th and $\mathrm{U}$, vanadinite for $\mathrm{Pb}$, synthetic phosphates prepared by Jarosewich \& Boatner (1991) for the REE, and natural minerals and synthetic oxides for other elements. Accuracy of the calibration was checked routinely using synthetic $\mathrm{ThO}_{2}$ and $\mathrm{UO}_{2.15}$, synthetic glass SRM 610, which contains some hundred $\mathrm{ppm}$ of $\mathrm{Th}, \mathrm{U}$, and $\mathrm{Pb}$, a synthetic glass containing 0.79 wt.\% $\mathrm{PbO}$, and the REE glasses prepared by Drake \& Weill (1972). Reproducibility of the stated compositions in the SRM 610 glass was better than $15 \%$, that in the REE glasses, better than $5-10 \%$. A further check on calibration was made by 
determining the stoichiometry and composition of an in-house monazite standard analyzed in different laboratories.

The analytical errors associated with the REE depend on the absolute abundances of each element. Relative errors are estimated to be $<1 \%$ at the $>10 \mathrm{wt}$. $\%$ level, 5$10 \%$ at the 1 wt. $\%$ level, $10-20 \%$ at the 0.2 to 1 wt. $\%$ level, and $20-40 \%$ at the $<0.1$ wt. $\%$ level. For concentrations below $0.1 \mathrm{wt} . \%$, the analytical precision for the actinides and for lead is much higher, approximately $10 \%$. Detection limits were approximately 200-300 ppm for all elements monitored except lead ( 100 ppm).

In an early stage of the investigation, the huttonite grains were also analyzed for $\mathrm{Al}, \mathrm{Tb}, \mathrm{Ho}, \mathrm{Er}, \mathrm{Yb}$, and $\mathrm{Lu}$, but the measured concentrations were found to be mostly at or below their detection limits.

\section{$X$-ray diffraction}

One huttonite grain and one thorite grain were selected from one crystal for X-ray examination. The single-crystal patterns were made with a Gandolfi camera $57.3 \mathrm{~mm}$ in diameter under standard analytical conditions. Huttonite was confirmed by the strongest lines of its X-ray-diffraction pattern $[d$ in $\AA(h k l)]: 4.67(011)$, 4.04(101), 3.49(111), 3.24(200), 3.08(120), and $2.86(012)$. Identification of thorite was made on the basis of the following lines: 4.71(101), 3.56(200), 2.84(211), 2.67(112), 2.22(301), and 1.82(312).

\section{Chemical Composition}

\section{Huttonite}

Electron-microprobe analyses were performed on three single, anhedral grains (between $50 \times 100 \mu \mathrm{m}$ and $150 \times 250 \mu \mathrm{m}$ in size), embedded in epoxy, in a grain mount (Figs. 1a, b). Back-scattered electron imaging revealed no visible zonation (Fig. 1c). Between 15 and 18 spot analyses were performed on each crystal to evaluate compositional variability.

The composition of huttonite is dominated by the major components $\mathrm{Th}\left(78.0 \leq \mathrm{ThO}_{2} \leq 80.3 \mathrm{wt} . \%\right)$ and $\mathrm{Si}\left(18.4 \leq \mathrm{SiO}_{2} \leq 19.1 \mathrm{wt} . \%\right)$. $\mathrm{P}$ and $\mathrm{U}$ are always present at the tenths of a wt.\% level $\left(0.11 \leq \mathrm{P}_{2} \mathrm{O}_{5} \leq 0.68\right.$ wt.\%; $0.54 \leq \mathrm{UO}_{2} \leq 0.82$ wt. \%). The sum of $\mathrm{Y}_{2} \mathrm{O}_{3}$ and $R E E_{2} \mathrm{O}_{3}$ ranges from 0.3 to 1.4 wt.\%. Y, Nd, Sm, Gd, and Dy are invariably present in concentrations above their detection limits; however, $\mathrm{La}, \mathrm{Ce}$, and $\mathrm{Pr}$ are not. Iron concentrations are almost negligible $(<0.01-0.03 \mathrm{wt} . \%$ $\mathrm{FeO}$ ). The same holds true for $\mathrm{Ca}$. The analytical totals are invariably very close to $100 \%$, and the cation proportions indicate a perfect stoichiometric composition. With respect to formula units, the following range of decreasing importance among the individual lanthanides can be established: Y > Gd,Nd > Ce,Sm,Dy > La,Pr.

The within-grain compositional variability is small. However, there is some variability among the grains
(Table 1). Huttonite 1 is highest in the light-rare-earth elements ( $L R E E)$, with a proportion of $L R E E_{2} \mathrm{O}_{3}$ to $\left(\mathrm{Y}_{2} \mathrm{O}_{3}+H R E E_{2} \mathrm{O}_{3}\right)$ between 1 and 2 . In grains 2 and 3, $\mathrm{Y}$ and the HREE predominate over the LREE. The chondrite-normalized $R E E$ patterns are umbrella-like and characterized by a slight and systematic increase from La to Gd (probably with exception of Eu), followed by a decrease to Dy and Y, which can be expected to proceed continuously to Lu.

In terms of mole fractions, $\mathrm{ThSiO}_{4}$ is the overwhelming component (93.2-98.4 mol.\%). Between 0.7 and 1.0 mol.\% $\mathrm{USiO}_{4}$ is present. The monazite $\left(L R E E \mathrm{PO}_{4}\right)$ component amounts to $0.1-1.4 \mathrm{~mol} \%$. (Y,HREE) $\mathrm{PO}_{4}$ accounts for $0.3-2.5 \mathrm{~mol} \%$ of the huttonite composition. The brabantite, $\mathrm{CaTh}\left(\mathrm{PO}_{4}\right)_{2}$, component is very subordinate $(<0.3 \mathrm{~mol} . \%)$. Incorporation of the REE and $\mathrm{Y}$ into the huttonite structure takes place mainly by the coupled substitution $R E E^{3+}+\mathrm{P}^{5+} \Leftrightarrow \mathrm{Th}^{4+}+\mathrm{Si}^{4+}$.

TABLE 1, RESULTS OF ELECTRON-MICROPROBE ANALYSES OF HUTTONITE FROM GILLESPIE'S BEACH, NEW ZEALAND

\begin{tabular}{|c|c|c|c|c|c|c|c|}
\hline \multirow[b]{2}{*}{$\mathrm{P}_{2} \mathrm{O}_{3}$ wt $\%$} & \multicolumn{2}{|c|}{$\begin{array}{l}\text { grain } 1(n=16) \\
\text { average } 1 \text { o STD }\end{array}$} & \multicolumn{2}{|c|}{$\begin{array}{c}\text { grain } 2(n=15) \\
\text { average } 10 \text { STD }\end{array}$} & $\begin{array}{r}\text { grain } 3 \\
\text { average }\end{array}$ & grain $3(n=17)$ & $\begin{array}{l}\text { Type } \\
\text { Htn }\end{array}$ \\
\hline & 0.38 & 0.11 & 0.36 & 0.10 & 0.53 & 0.12 & $\mathrm{tr}$ \\
\hline $\mathrm{SiO}_{2}$ & 18.73 & 0.09 & 18.77 & 0.14 & 18.83 & 0.22 & 19.7 \\
\hline $\mathrm{ThO}_{2}$ & 79.09 & 0.37 & 79.54 & 0.31 & 79.05 & 0.64 & 76.6 \\
\hline $\mathrm{UO}_{2}$ & 0.70 & 0.07 & 0.71 & 0.02 & 0.59 & 0.04 & 0 \\
\hline $\mathrm{Y}_{2} \mathrm{O}_{3}$ & 0.28 & 0.07 & 0.27 & 0.07 & 0.47 & 0.16 & \\
\hline $\mathrm{La}_{2} \mathrm{O}_{3}$ & 0.03 & 0.02 & 0.01 & 0.02 & 0.01 & 0.01 & \\
\hline $\mathrm{Ce}_{2} \mathrm{O}_{3}$ & 0.14 & 0.04 & 0.02 & 0.02 & 0.04 & 0.02 & \\
\hline $\mathrm{Pr}_{2} \mathrm{O}_{3}$ & 0.04 & 0.02 & 0.01 & 0.02 & 0.02 & 0.02 & 2.6 \\
\hline $\mathrm{Nd}_{2} \mathrm{O}_{3}$ & 0.22 & 0.06 & 0.05 & 0.03 & 0.09 & 0.03 & \\
\hline $\mathrm{Sm}_{2} \mathrm{O}_{3}$ & 0.08 & 0.04 & 0.03 & 0.03 & 0.07 & 0.05 & \\
\hline $\mathrm{Gd}_{2} \mathrm{O}_{3}$ & 0.12 & 0.03 & 0.08 & 0.02 & 0.11 & 0.06 & \\
\hline $\mathrm{Dy}_{2} \mathrm{O}_{3}$ & 0.06 & 0.04 & 0.05 & 0.04 & 0.08 & 0.04 & \\
\hline $\mathrm{CaO}$ & 0 & 0 & 0.02 & 0.01 & 0.02 & 0.01 & 0 \\
\hline $\mathrm{FeO}$ & 0.01 & 0.01 & 0.01 & 0.01 & 0.01 & 0.01 & 1.3 \\
\hline $\mathrm{PbO}$ & 0.04 & 0.01 & 0.03 & 0.01 & 0.03 & 0.01 & \\
\hline sum & 99.93 & 0.30 & 99.96 & 0.19 & 99,96 & 0.42 & 100.3 \\
\hline Р apfu & 0.068 & 0.019 & 0.064 & 0.017 & 0.095 & 0.020 & \\
\hline $\mathrm{Si}$ & 3.987 & 0.017 & 3.994 & 0.025 & 3.982 & 0.030 & 4.103 \\
\hline $\mathrm{Th}$ & 3.831 & 0.020 & 3.852 & 0.022 & 3.803 & 0.048 & 3.635 \\
\hline U & 0.033 & 0.003 & 0.034 & 0.001 & 0.028 & 0.002 & \\
\hline$Y$ & 0.032 & 0.007 & 0.030 & 0.008 & 0.053 & 0.017 & \\
\hline $\mathrm{La}$ & 0.002 & 0.002 & 0.001 & 0.001 & 0.001 & 0.001 & \\
\hline $\mathrm{Ce}$ & 0.011 & 0.004 & 0.001 & 0.001 & 0,003 & 0.001 & 0.198 \\
\hline $\mathrm{Pr}$ & 0.003 & 0.001 & 0.001 & 0.001 & 0.001 & 0.001 & \\
\hline Nd & 0.016 & 0.004 & 0.004 & 0.003 & 0.007 & 0.002 & \\
\hline $\mathrm{Sm}$ & 0.006 & 0.003 & 0.002 & 0,002 & 0.005 & 0.003 & \\
\hline $\mathrm{Gd}$ & 0.008 & 0.002 & 0.006 & 0.002 & 0.008 & 0.004 & \\
\hline Dy & 0.004 & 0.003 & 0.004 & 0.003 & 0.005 & 0.003 & \\
\hline $\mathrm{Ca}$ & & & 0.005 & 0.003 & 0.005 & 0.003 & \\
\hline $\mathrm{Fe}$ & 0.001 & 0.001 & 0.001 & 0.002 & 0.002 & 0.002 & 0.2226 \\
\hline $\mathrm{Pb}$ & 0.002 & 0.001 & 0.002 & & 0.001 & 0.001 & \\
\hline total & 8.005 & 0.004 & 8.000 & 0.002 & 8.001 & 0.003 & 8.163 \\
\hline Age $(\mathrm{Ma})$ & 13.2 & 3.1 & 8.5 & 2.3 & 8.6 & 3.2 & \\
\hline
\end{tabular}

The proportion of cations, in atoms per formula unit, is calculated on the basis of 16 atoms of oxygen; blank spaces: elements not sought, 0 : analyzed but not detected; tr.: trace. STD: standard deviation; $n$ : number of spots analyzed. Type Htn: type-locality huttonite (Pabst \& Hutton 1951) 

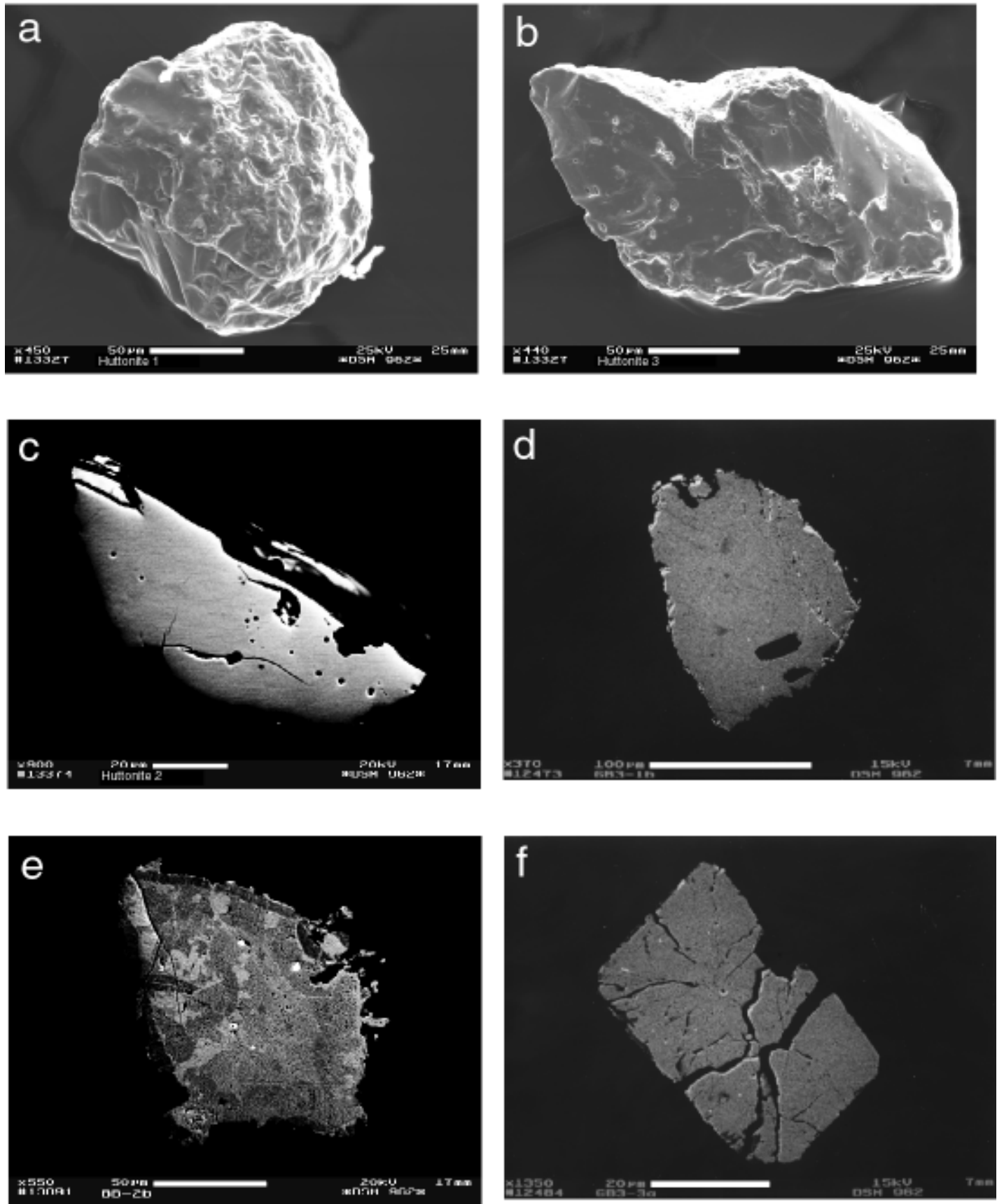

FIG. 1. Scanning electron microscope (SEM) and back-scattered electron (BSE) microphotographs of huttonite and thorite grains from Gillespie's Beach. (a) and (b): SEM images of typical grains of huttonite as provided by the Smithsonian Institution. (c) BSE image of one of the mounted grains of huttonite analyzed by electron microprobe. (d) BSE image of an anhedral, homogeneous grain of thorite. (e) BSE image of a thorite grain showing striking patchy zoning. (f) BSE image of a euhedral, unzoned and cracked grain of thorite. 


\section{Thorite}

The grains range in size from $30 \times 50 \mu \mathrm{m}$ to $150 \times$ $250 \mu \mathrm{m}$. Most of them are anhedral to subhedral, seem homogeneous or are only weakly zoned (Fig. 1d). Some grains exhibit strong zonation (Fig. 1e). Euhedral crystals are rare (Fig. 1f). Usually, the grains are corroded, cracked and contain a scattering of holes or tiny inclusions.

Thorium $\left(69.8 \leq \mathrm{ThO}_{2} \leq 79.1\right.$ wt. $\left.\%\right)$ and $\mathrm{Si}(18.4 \leq$ $\mathrm{SiO}_{2} \leq 19.1$ wt.\%) dominate as constituents (Table 2). However, the thorite also contains high but variable contents of $\mathrm{U}\left(1.8 \leq \mathrm{UO}_{2} \leq 9.5 \mathrm{wt} . \%\right)$. $\mathrm{P}$ is present at a level of a few tenths of a wt.\% $\left(0.01 \leq \mathrm{P}_{2} \mathrm{O}_{5} \leq 0.41\right.$ wt.\%). The sum of $\mathrm{Y}_{2} \mathrm{O}_{3}$ and $R E E_{2} \mathrm{O}_{3}$ is low and ranges from 0.01 to $0.89 \mathrm{wt} . \%$. The proportions of $L R E E_{2} \mathrm{O}_{3}$ to
$\left(\mathrm{Y}_{2} \mathrm{O}_{3}+H R E E_{2} \mathrm{O}_{3}\right)$ are variable, in the range $<0.2$ to 2.1. Thorite contains between 0.01 and $0.49 \mathrm{wt} . \% \mathrm{CaO}$ and 0.14 and 0.89 wt.\% $\mathrm{PbO}$. Fe and $\mathrm{Al}$ concentrations are negligibly low $(<0.01 \mathrm{wt} . \%)$. The totals are close to $100 \%$, and the cation proportions match the ideal stoichiometry of thorite very closely.

In terms of mole fractions, $\mathrm{ThSiO}_{4}$ is the overwhelming component (86.3-96.7 mol.\%). Between 2.1 and $11.3 \mathrm{~mol} \% \mathrm{USiO}_{4}$ is present, whereas (Y,HREE) $\mathrm{PO}_{4}$ accounts for $0.1-3.2 \mathrm{~mol} \%$ of the composition.

\section{Mineral Ages}

Actinide-bearing accessory minerals bear the potential for $\mathrm{Th}-\mathrm{U}-$ total $\mathrm{Pb}$ age dating by electron microprobe (e.g., Suzuki \& Adachi 1991, Rhede et al. 1996,

TABLE 2. RESULTS OF ELECTRON-MICROPROBE ANALYSES

OF THORITE FROM GILLESPIE'S BEACH, NEW ZEALAND

\begin{tabular}{|c|c|c|c|c|c|c|c|c|c|c|c|}
\hline $\begin{array}{l}\text { grain no. } \\
\text { anal. no. }\end{array}$ & $\begin{array}{c}\text { BB-2a } \\
1\end{array}$ & $\begin{array}{c}\mathrm{BB}-2 \mathrm{a} \\
2\end{array}$ & $\begin{array}{c}\text { BB- } 2 b \\
3\end{array}$ & $\begin{array}{c}\text { GB3-1b } \\
4\end{array}$ & $\begin{array}{c}\text { GB3-1b } \\
5\end{array}$ & $\begin{array}{c}\text { GB3-1a } \\
6\end{array}$ & $\begin{array}{c}\mathrm{GB} 1-5 \mathrm{a} \\
7\end{array}$ & $\begin{array}{c}G B I-5 a \\
8\end{array}$ & $\begin{array}{c}\text { BB-2b } \\
9\end{array}$ & $\begin{array}{c}\text { GB3-2b } \\
10\end{array}$ & $\begin{array}{c}\text { GB3-3a } \\
11\end{array}$ \\
\hline $\mathrm{P}_{2} \mathrm{O}_{3}$ wt. $\%$ & 0.10 & 0.06 & 0.03 & 0.05 & 0.03 & 0.06 & 0.14 & 0.12 & 0.20 & 0.20 & 0.27 \\
\hline $\mathrm{SiO}_{2}$ & 18.61 & 18.76 & 18.73 & 19.12 & 18.98 & 19.01 & 18.93 & 18.68 & 18.87 & 18.68 & 18.79 \\
\hline $\mathrm{ThO}_{2}$ & 74.79 & 79.07 & 78.04 & 74.78 & 72.80 & 72.87 & 75.16 & 74.51 & 75.11 & 74.52 & 70.01 \\
\hline $\mathrm{UO}_{2}$ & 6.01 & 1.78 & 3.03 & 5.15 & 7.36 & 5.95 & 4.80 & 4.84 & 4.13 & 4.22 & 7.79 \\
\hline $\mathrm{Y}_{2} \mathrm{O}_{3}$ & 0 & 0.03 & 0.08 & 0.12 & 0.06 & 0.63 & 0.17 & 0.19 & 0.29 & 0.24 & 0.37 \\
\hline $\mathrm{La}_{2} \mathrm{O}_{3}$ & 0 & 0 & 0.02 & 0 & 0 & 0 & 0.01 & 0 & 0 & 0 & 0 \\
\hline $\mathrm{Ce}_{2} \mathrm{O}_{3}$ & 0 & 0.04 & 0.09 & 0.09 & 0.03 & 0.11 & 0.03 & 0.11 & 0.12 & 0.19 & 0.14 \\
\hline $\mathrm{Pr}_{2} \mathrm{O}_{3}$ & 0 & 0 & 0 & 0 & 0 & 0 & 0.03 & 0 & 0 & 0.07 & 0.00 \\
\hline $\mathrm{Nd}_{2} \mathrm{O}_{3}$ & 0 & 0.01 & 0.05 & 0.05 & 0.05 & 0.08 & 0.15 & 0.05 & 0.15 & 0.06 & 0.18 \\
\hline $\mathrm{Sm}_{2} \mathrm{O}_{3}$ & 0 & 0 & 0 & 0 & 0.04 & 0 & 0.04 & 0 & 0 & 0.09 & 0.02 \\
\hline $\mathrm{Gd}_{2} \mathrm{O}_{3}$ & 0 & 0.03 & 0.00 & 0.05 & 0 & 0.12 & 0.04 & 0 & 0 & 0.03 & 0.09 \\
\hline $\mathrm{Tb}_{2} \mathrm{O}_{3}$ & 0 & 0 & 0 & 0 & 0 & 0 & 0.02 & 0.01 & 0.03 & 0 & 0 \\
\hline $\mathrm{Dy}_{2} \mathrm{O}_{3}$ & 0 & 0 & 0.05 & 0 & 0.04 & 0.15 & 0.10 & 0.03 & 0.08 & 0.04 & 0.14 \\
\hline $\mathrm{Ho}_{2} \mathrm{O}_{3}$ & 0 & 0 & 0.01 & 0 & 0 & 0 & 0 & 0 & 0 & 0 & 0 \\
\hline $\mathrm{Er}_{2} \mathrm{O}_{3}$ & 0 & 0 & 0 & 0 & 0 & 0.03 & 0 & 0 & 0 & 0 & 0.03 \\
\hline $\mathrm{Yb}_{2} \mathrm{O}_{3}$ & 0 & 0 & 0 & 0 & 0 & 0 & 0 & 0.01 & 0.04 & 0 & 0 \\
\hline $\mathrm{CaO}$ & 0.11 & 0.03 & 0.01 & 0.12 & 0.13 & 0.27 & 0.13 & 0.05 & 0.12 & 0.39 & 0.06 \\
\hline $\mathrm{PbO}$ & 0.31 & 0.26 & 0.29 & 0.29 & 0.28 & 0.28 & 0.35 & 0.59 & 0.52 & 0.57 & 0.85 \\
\hline total & 99.93 & 100.07 & 100.43 & 99.82 & 99.80 & 99.56 & 100.08 & 99.18 & 99.86 & 99.30 & 98.78 \\
\hline Р apfu & 0.017 & 0.011 & 0.005 & 0.008 & 0.005 & 0.012 & 0.025 & 0.021 & 0.036 & 0.036 & 0.049 \\
\hline $\mathrm{Si}$ & 4.006 & 4.024 & 4.015 & 4.075 & 4.061 & 4.051 & 4.034 & 4.031 & 4.025 & 4.007 & 4.039 \\
\hline Th & 3.663 & 3.859 & 3.805 & 3.627 & 3.545 & 3.534 & 3.646 & 3.659 & 3.646 & 3.637 & 3.424 \\
\hline $\mathrm{U}$ & 0.288 & 0.085 & 0.144 & 0.244 & 0.351 & 0.282 & 0.228 & 0.233 & 0.196 & 0.201 & 0.373 \\
\hline$X$ & & 0.003 & 0.009 & 0.014 & 0.007 & 0.071 & 0.019 & 0.021 & 0.033 & 0.028 & 0.042 \\
\hline $\mathrm{La}$ & & & 0.002 & & & & 0.001 & & 0.005 & & \\
\hline $\mathrm{Ce}$ & & 0.003 & 0.007 & 0.007 & 0.002 & 0.009 & 0.002 & 0.009 & 0.009 & 0.015 & 0.011 \\
\hline $\operatorname{Pr}$ & & & & & & & 0.002 & & 0,004 & 0.005 & \\
\hline $\mathrm{Nd}$ & & 0.001 & 0.004 & 0.004 & 0.004 & 0.006 & 0.011 & 0.004 & 0.012 & 0.005 & 0.014 \\
\hline $\mathrm{Sm}$ & & & & & 0.003 & & 0.003 & & 0.002 & 0.007 & 0.002 \\
\hline $\mathrm{Gd}$ & & 0.002 & & 0.003 & & 0.009 & 0.003 & & & 0.002 & 0.007 \\
\hline $\mathrm{Tb}$ & & & & & & & 0.001 & & 0.002 & & \\
\hline Dy & & & 0.004 & & 0.003 & 0.010 & 0.007 & 0.002 & 0.005 & 0.003 & 0.010 \\
\hline Ho & & & 0.001 & & & & & & 0.001 & & \\
\hline Er & & & & & & 0.002 & & & 0.003 & & 0.002 \\
\hline $\mathrm{Yb}$ & & & & & & & & 0.001 & 0.002 & & \\
\hline $\mathrm{Ca}$ & 0.026 & 0.006 & 0.001 & 0.026 & 0.029 & 0.062 & 0.030 & 0.011 & 0.028 & 0.089 & 0.014 \\
\hline $\mathrm{Pb}$ & 0.018 & 0.015 & 0.017 & 0.017 & 0.016 & 0.016 & 0.020 & 0.034 & 0.030 & 0.033 & 0.049 \\
\hline total & 8.018 & 8.010 & 8.014 & 8.026 & 8.026 & 8.063 & 8.031 & 8.027 & 8.040 & 8.068 & 8.043 \\
\hline age (Ma) & 78 & 72 & 79 & 75 & 69 & 72 & 70 & 155 & 138 & 152 & 210 \\
\hline
\end{tabular}

The proportion of cations, in $a p f u$, is calculated on the basis of 16 atoms of oxygen. 0 : sought but not detected. 
Montel et al. 1996). The most recent attempts to obtain "chemical ages" have focussed on monazite-(Ce) (e.g., Suzuki et al. 1994, Braun et al. 1998, Cocherie et al. 1998, Finger \& Helmy 1998, Crowley \& Ghent 1999). Other minerals used for this purpose include zircon (Tadesse et al. 1997, Kato et al. 1997, Geisler \& Schleicher 2000), xenotime (Ito et al. 1997, Förster et al. 1999) and uraninite (Förster 1999).

Given their high concentrations of Th $( \pm U)$, the actinide orthosilicates huttonite and thorite bear a great potential for calculation of "chemical ages", if not metamict or altered. Metamictization and resultant hydration are accompanied by a strong disturbance in the $\mathrm{U}-\mathrm{Th}-\mathrm{Pb}$ system. Minerals of the monazite group, including huttonite, are less susceptible to radiation damage leading to amorphization than other accessory phases, and, therefore, metamict phases of that group are rarely observed in nature (Boatner \& Sales 1988, Meldrum et al. 1998). Indeed, the well-developed Xray-diffraction pattern of huttonite from Gillespie's Beach indicates a high degree of crystallinity. On the other hand, thorite, which crystallizes with the structure of zircon, usually occurs in the metamict state (e.g., Farges \& Calas 1991). Therefore, thorite has been used for $\mathrm{Th}-\mathrm{U}-$ total $\mathrm{Pb}$ dating only twice, though with limited success (Parslow et al. 1985, Enami et al. 1993). In the case of thorite from Gillespie's Beach, the X-ray pattern of the grain investigated does not show a measurable degree of amorphization. Moreover, totals close to $100 \mathrm{wt} . \%$, a nearly ideal stoichiometry, and low to very low levels of $\mathrm{Al}, \mathrm{Fe}$, and $\mathrm{Ca}$ are incompatible with metamictization. Consequently, both huttonite and thorite studied in this paper seem suited as mineralogical geochronometers.

Single-point ages for huttonite, calculated using the equation for the radioactive decay of $\mathrm{U}$ and $\mathrm{Th}$ and the decay constants proposed by Steiger \& Jäger (1977), range from 5.7 to $18.3 \mathrm{Ma}$. Average ages for each of the three huttonite grains are given in Table 1 . The relatively high standard deviations are an expression of some inhomogeneity in age on the scale of the grain, but no systematic core-rim relations were detected. Statistical handling of single-point ages yields three distinct age-populations: $15.4 \pm 1.6 \mathrm{Ma}, 10.7 \pm 1.3 \mathrm{Ma}$, and $5.8 \pm 1.3 \mathrm{Ma}$.

Single-point ages for thorite extend over a considerably more lengthy time-interval, from 35 to $210 \mathrm{Ma}$. Grains of different compositional and geochronological relations occur: compositionally and geochronologically homogeneous grains (GB3-3a; Table 2, anal. 11), chemically heterogeneous but geochronologically homogeneous grains (GB3-1b; Table 2; anals. 4 and 5), chemically homogeneous but geochronologically heterogeneous grains (GB1-5a; Table 2, anals. 7 and 8) and compositionally and geochronologically zoned grains (BB-2b; Table 2, anals. 3 and 9). Four statistically distinct age-populations can be distinguished $( \pm 1 \sigma$ standard deviation): $205-210 \mathrm{Ma}(n=2$; Triassic-
Jurassic boundary), $152 \pm 9 \mathrm{Ma}$ ( $n=5$; late Jurassic), $76 \pm 6 \mathrm{Ma}(n=18$; late Cretaceous), and $41 \pm 5 \mathrm{Ma}(n$ $=3$; early Tertiary, Eocene). The majority of the grains studied, either geochronologically homogeneous or not, record a late Cretaceous age (Table 2, anals. 1-7).

\section{Discussion}

\section{Overall composition of huttonite from the type locality}

The electron-microprobe data for the huttonite presented here show poor correspondence with the wetchemical analytical results of the type material reported by Pabst \& Hutton (1951) (Table 1). A broad similarity is observed only for the major components, Th and Si. $\mathrm{U}$ and $\mathrm{P}$ were not detected by Pabst \& Hutton (1951) but are present in our huttonite grains. In contrast, Y plus the $R E E$ are incorporated in the latter grains at a much lower concentration than measured in the type material. Moreover, considerable amounts of $\mathrm{Fe}_{2} \mathrm{O}_{3}(1.2$ wt.\%) determined in the type-huttonite separate were not detected in the grains studied by electron microprobe. The differences in the analytical data may be the result of one or more of the following reasons: (1) they correctly reflect the natural variability in the huttonite composition, (2) the type material was not completely purified (for example, Fe oxides may have been present in fission-track voids, fissures, holes, etc.), and (3) the original analysis was affected by analytical problems.

\section{REE pattern of huttonite}

The recognized proportions between the $L R E E$ and HREE and the shape of the chondrite-normalized REE patterns (Fig. 2) do not match the general composition of other minerals of the monazite group, including monazite-(Ce), cheralite-(Ce), and brabantite, which typically have a strong preference for the LREE (see Förster 1998, and references therein). The predominance of Gd in the patterns, however, can be easily explained in terms of charge and ionic radius of the substituting elements. The ionic radius of trivalent ${ }^{\mathrm{VI}} \mathrm{Gd}(0.938 \AA$ A: Shannon 1976) is closest to tetravalent ${ }^{\mathrm{VI}} \mathrm{Th}(0.94 \AA)$ relative to all other $R E E$ and $\mathrm{Y}$. From $\mathrm{Gd}$, the ionic radii of the ${ }^{\mathrm{VI}} L R E E$ increase continuously toward La (1.01 $\AA)$. Those of the HREE decrease in the same manner toward Lu (0.861 $\AA$ ). Consequently, the mineral/melt (or fluid) partition coefficient should be greater for $\mathrm{Gd}$ than for the other REE. Clearly, the shape of the REE pattern of huttonite indicates that the partitioning of the lanthanides and Y between huttonite and the melt (or fluid) from which it crystallized was predominantly a function of charge and the ionic radius of the elements involved. The REE distribution patterns in huttonite from Gillespie's Beach should be representative of huttonite in general, as long as the behavior of the elements is a smooth function of ionic radius. However, huttonite precipitated from aqueous solutions or pegma- 


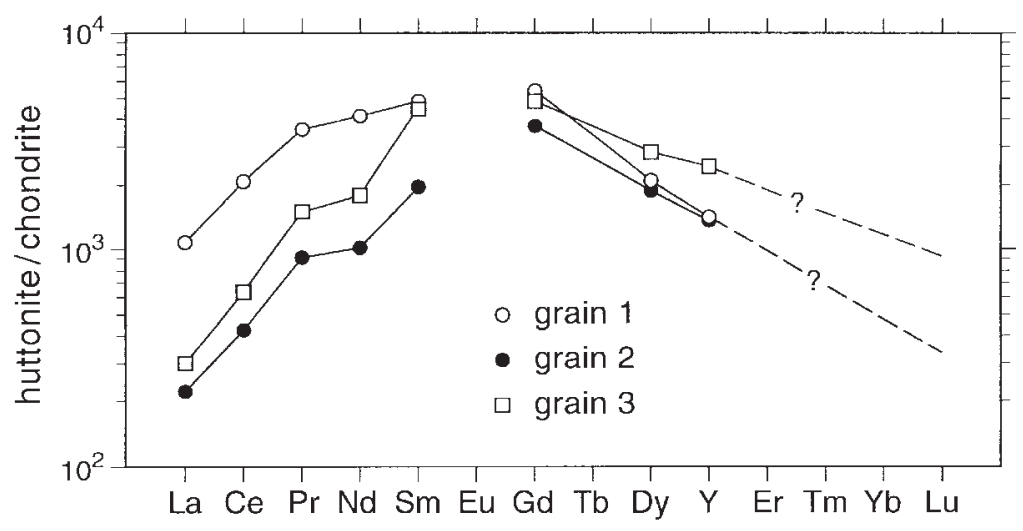

FIG. 2. Chondrite-normalized REE patterns of three huttonite grains from Gillespie's Beach. Chondrite data are from Anders \& Grevesse (1989).

tite-forming granitic melts enriched in volatiles may show distinct REE patterns. In these media, chemical complexation, depending on electron configuration and the type of complexing ligand, may cause significant fractionation of the elements (e.g., Bau 1996).

\section{$\mathrm{ThSiO}_{4}$ ages and the regional geology of South Island}

Gillespie's Beach is located in southern Westland Province of South Island. This province contains part of the Tasman Metamorphic Belt (TMB), flanked to the northwest by the South Westland Basin (e.g., Sircombe \& Kamp 1998) and to the southeast by the Southern Alps mountain belt. This belt belongs to the Wakatipu Metamorphic Belt (WMB) in the Eastern Province of South Island. Both metamorphic belts are divided by the Alpine Fault, positioned about $20 \mathrm{~km}$ southeast of Gillespie's Beach. South Island is regarded as comprising a zone of oblique continent-continent collision involving the Pacific (WMB) and Australia plates (TMB) (Kamp \& Tippett 1993, Tippett \& Kamp 1993, Beaumont et al. 1996). The Alpine Fault is the suture zone between the two plates, and the Southern Alps, the topographic expression of uplift and erosion of the leading edge of the Pacific Plate (e.g., Sircombe \& Kamp 1998).

Pabst \& Hutton (1951) concluded, from the nature of the associated heavy minerals, that the medium-grade (Otago) schists of the Southern Alps were the source of both the huttonite and thorite present in the sands of Gillespie's Beach. From the viewpoint of the U - Th total $\mathrm{Pb}$ ages of the huttonite grains, it can be established that in the Otago schists, $\mathrm{Rb}-\mathrm{Sr}$ and $\mathrm{K}-\mathrm{Ar}$ mineral ages between 4 and $7 \mathrm{Ma}$ were obtained (Harper \& Landis 1967 , and references therein). Of particular interest is that these young ages are measured only in schists that occur spatially close to Gillespie's Beach. The second youngest population of ages of huttonite is contempo- raneous with the starting point of plate convergence along the Alpine fault ( $10 \mathrm{Ma}$, Beaumont et al. 1996).

Within a distance of about $75 \mathrm{~km}$ from Gillespie's Beach, no ages are reported that would match the age data obtained from the grains of thorite. Here, metamorphic ages ranging from 60 to $76 \mathrm{Ma}$ were measured in the Otago schists. These roughly correspond to the age of population 3 recorded in the thorite. At about the same distance from Gillespie's Beach, late Cretaceous metamorphic ages of 133-141 Ma are measured in these schists. These are only slightly younger than the ages represented by population 2 . About $200 \mathrm{~km}$ away from Gillespie's Beach, metamorphic rocks have been found with ages between 52 and $55 \mathrm{Ma}$. These are slightly older than the ages reflected by population 4 .

Ages around $200 \mathrm{Ma}$, as given by population 1, are not measured in any metamorphic rock from South Island. However, in the Tasman Metamorphic Belt, a number of plutonic rocks of appropriate ages are exposed. These rocks occur in the Nelson and Fjordlands blocks to the northeast and southwest, respectively, of Gillespie's Beach. Late Triassic to early Jurassic ages are displayed by granitic cobbles in conglomerates (226 $\pm 6 \mathrm{Ma}$, Graham \& Korsch 1990), the Sams Creek peralkaline granite (226 $\pm 1.1 \mathrm{Ma}$, Tulloch 1992), and some metarhyolites ( $200 \mathrm{Ma}$, King et al. 1985). A younger, major subduction-related event consisting of I-type magmatism occurred between 156 and $130 \mathrm{Ma}$ (Kimbrough et al. 1993, 1994a). This event correlates with the age of mid-Mesozoic peak metamorphism, as manifested by the Fraser Complex of amphibolite-facies gneisses (157 $\pm 21 \mathrm{Ma}$, Kimbrough et al. 1994b). The thorite ages are not compatible with the time of the mid-Cretaceous (117-107 Ma) emplacement of voluminous collision-related granites (Kimbrough et al. 1993, Muir et al. 1994, Waight et al. 1998) nor with a period of granulite-facies metamorphism in the Western Province (110-125 Ma: Ireland \& Gibson 1998). Intrusion 
of the youngest Cretaceous granite, the French Creek A-type granite, took place at about $83 \mathrm{Ma}$, which is roughly similar to thorite age-population 3 . Inclusion of I- and A-type granites in a discussion of possible sourcerocks for thorite grains from Gillespie's Beach reflects the fact that these granites and their metamorphic equivalents are the most important hosts of thorite in nature (e.g., Feely et al. 1989, Egeberg et al. 1993, Casillas et al. 1995, Bingen et al. 1996, Finger et al. 1998, Förster et al. 1999).

Correspondences between ages determined from the huttonite and thorite grains and times of important metamorphic and magmatic events in South Island suggest that their $\mathrm{Th}-\mathrm{U}-$ total $\mathrm{Pb}$ ages may be real. If so, they record either multiple stages of mineral growth or the resetting of the $\mathrm{Th}-\mathrm{U}-\mathrm{Pb}$ isotopic system that occurred between the late Triassic and late Tertiary on South Island. In such a scenario, the thorite ages imply that metamorphic or magmatic rocks older than the Cretaceous should occur at a closer distance to Gillespie's Beach than is implied from recent geological maps. However, we do not wish to overinterpret the chemical ages. We cannot totally exclude the possibility that both actinide orthosilicates (in particular thorite) may have undergone fluid-induced loss of $\mathrm{Pb}$. This may explain the scatter in the ages as well as the young age-populations.

\section{Huttonite-thorite stability relations}

The suggested source of huttonite from Gillespie's Beach, the Otago schists, are of medium-grade origin. Maximum pressures and temperatures approach $7 \mathrm{kbar}$ and $500^{\circ} \mathrm{C}$ (Yardley 1982). Pressures up to $12 \mathrm{kbar}$ are estimated for the granulite-facies orthogneisses from the Western Province, but these are older, of Cretaceous age. The Otago schists and all other known rocks of Miocene age experienced P-T metamorphic conditions well outside the experimentally calibrated range of stability of huttonite (e.g., Dachille \& Roy 1964, Seydoux $\&$ Montel 1997). This inference suggests that undiscovered high-P rocks may occur within the source area from which the beach-sand material was derived. However, no high-pressure metamorphic minerals, such as jadeite or glaucophane, are described by Pabst \& Hutton (1951), nor were they detected in the thorite-containing sands studied by us. It may also be possible that the available experimental data do not correctly describe the huttonite-thorite stability relations, since the experiments were not reversed. Speer (1982) has suggested that admixtures of other elements such as the REE may increase the stability field of huttonite. However, in the case of huttonite from Gillespie's Beach, element abundances other than Th and Si are virtually too low to dramatically increase its stability. To resolve the apparent problem of incompability between experimental results and observations in natural systems, a redetermination of the stability field of huttonite relative to thorite, both with and without minor REE, is long overdue.

\section{ACKNOWLEDGEMENTS}

The huttonite grains were kindly provided by $\mathrm{M}$. Wise, curator of the Mineralogical Collection of the Smithsonian Institution in Washington, D.C. M. Hertel, Tübingen, and T. Brinkman, Auckland, collected the thorite-bearing sands from Gillespie's Beach and Bruce Bay. We are thankful to O. Appelt, Potsdam, for assistance with the electron-microprobe work. The X-ray diffraction exposures were done by O. Medenbach, Bochum. A.-M. Seydoux, Potsdam, examined and indexed the X-ray- diffraction patterns. Valuable reviews by R. Gault and an anonymous referee helped to improve the paper considerably.

\section{REFERENCES}

ÅMLI, R. \& GRIFFIN, W.L. (1975): Microprobe analysis of REE minerals using empirical correction factors. Am. Mineral. 60, 599-606.

Anders, E. \& GRevesse, N. (1989): Abundances of the elements: meteoric and solar. Geochim. Cosmochim. Acta 53, $197-214$.

BAU, M. (1996): Controls on the fractionation of isovalent trace elements in magmatic and aqueous systems: evidence from $\mathrm{Y} / \mathrm{Ho}, \mathrm{Zr} / \mathrm{Hf}$, and lanthanide tetrad effect. Contrib. Mineral. Petrol. 123, 323-333.

Beaumont, C., Kamp, P.J.J., Hamilton, J. \& Fullsack, P. (1996): The continental collision zone, South Island: comparison of geodynamical models and observations. $J$. Geophys. Res. B101, 3333-3359.

Bilal, E., Marciano, V., Neves, J.M.C., Fuzikawa, K., Riffel, B.F., NALini, H.A., Fernandes, M.L. \& NASRAOU,, M. (1998): Altération hydrothermale des monazites-(Ce) des pegmatites du district de Santa Maria de Itabira (Minas Gerais, Bresil). C.R. Acad. Sci., Sér. II, 326, 693-700.

Bingen, B., Demaiffe, D. \& Hertogen, J. (1996): Redistribution of rare earth elements, thorium, and uranium over accessory minerals in the course of amphibolite to granulite facies metamorphism: the role of apatite and monazite in orthogneisses from southwestern Norway. Geochim. Cosmochim. Acta 60, 1341-1354.

BoAtner, L.A. \& SAles, B.C. (1988): Monazite. In Radioactive Waste Forms for the Future (W. Lutze \& R.C. Ewing, eds.). Elsevier, Amsterdam, The Netherlands (495-564).

Braun, I., Montel, J.-M. \& Nicollet, C. (1998): Electron microprobe dating of monazites from high-grade gneisses and pegmatites of the Kerala Khondalite Belt, southern India. Chem. Geol. 146, 65-85. 
Broska, I., Petrík, I. \& Williams, C.T. (2000): Coexisting monazite and allanite in peraluminous granitoids of the Tribeč Mountains, western Carpathians. Am. Mineral. 85, 22-32.

Casillas, R., Nagy, G., Pantó, G., Brändle, J. \& Fórizs, I. (1995): Occurrence of Th, U, Y, Zr, and REE-bearing accessory minerals in late-Variscan granitic rocks from the Sierra de Guadarrama (Spain). Eur. J. Mineral. 7, 9891006.

Chakhmouradian, A.R. \& Sitnikova, M.A. (1999): Radioactive minerals from murmanite-lorenzenite tinguaite at Mt. Selsurt, Lovozero complex, Kola Peninsula. Eur. J. Mineral. 11, 871-878.

Cocherie, A., Legendre, O., Peucat, J.J. \& Kouamelan, A.N. (1998): Geochronology of polygenetic monazites constrained by in situ electron microprobe $\mathrm{Th}-\mathrm{U}$ - total lead determination: implications for lead behaviour in monazite. Geochim. Cosmochim. Acta 62, 2475-2497.

Crowley, J.L. \& GHENT, E.D. (1999): An electron microprobe study of the $\mathrm{U}-\mathrm{Th}-\mathrm{Pb}$ systematics of metamorphosed monazite: the role of $\mathrm{Pb}$ diffusion versus overgrowth and recrystallization. Chem. Geol. 157, 285-302.

DAchille, F. \& Roy, R. (1964): Effectiveness of shearing stresses in accelerating solid phase reactions at low temperatures and high pressures. J. Geol. 72, 243-47.

DraKe, M.J. \& WeILl, D.F. (1972): New rare earth elements standards for electron microprobe analysis. Chem. Geol. 10, 179-181.

Egeberg, A.T., Bonin, B. \& Sørensen, H. (1993): The Bonifatto peralkaline granites (NW Corsica): a possible case of evolution through volatile transfer. Bull. Soc. géol. France 164, 739-758.

Enami, M., SuZuki, K., Kingguo, Z. \& Xiangshen, Z. (1993): The chemical $\mathrm{Th}-\mathrm{U}$ - total $\mathrm{Pb}$ isochron ages of Jiaodong and Jiaonan metamorphic rocks in the Shandong Peninsula, eastern China. Island Arc 2, 104-113.

EXLEY, R.A. (1980): Microprobe studies of REE-rich accessory minerals: implications for Skye granite petrogenesis and REE mobility in hydrothermal systems. Earth Planet. Sci. Lett. 48, 97-110.

FARGes, F. \& CAlas, G. (1991): Structural analyses of radiation damage in zircon and thorite: an X-ray absorption spectroscopic study. Am. Mineral. 76, 60-73.

FeEly, M., McCabe, E. \& Williams, C.T. (1989): U-, Th- and REE-bearing accessory minerals in a high heat production leucogranite within the Galway Granite, western Ireland. Trans. Inst. Mining Metall. 98, B27-B32.

FinCH, C.B., HARRIS, L.A. \& ClaRK, G.W. (1964): The thoritehuttonite phase transformation as determined by growth of synthetic thorite and huttonite single crystals. Am. Mineral. 49, 782-785.
Finger, F., Broska, I., Roberts, M.P. \& Schermaier, A. (1998): Replacement of primary monazite by apatite allanite - epidote coronas in an amphibolite facies granite gneiss from the eastern Alps. Am. Mineral. 83, 248-258.

\& Helmy, H.M. (1998): Composition and total-Pb model ages of monazite from high-grade paragneisses in the Abu Swayel area, southern Eastern Desert, Egypt. Mineral. Petrol. 62, 269- 289.

FÖRSTER, H.-J. (1998): The chemical composition of REE-YTh-U-rich accessory minerals from peraluminous granites of the Erzgebirge-Fichtelgebirge region, Germany. I. The monazite-(Ce) - brabantite solid solution series. Am. Mineral. 83, 259-272.

(1999): The chemical composition of uraninite in Variscan granites of the Erzgebirge, Germany. Mineral. Mag. 63, 239-252.

\& HarLov, D.E. (1999): Monazite-(Ce) - huttonite solid solutions in granulite-facies metabasites from the Ivrea-Verbano Zone, Italy. Mineral. Mag. 63, 587-594.

Tischendorf, G., TRUMBull, R.B. \& GotTESMAnN, B. (1999): Late-collisional granites in the Variscan Erzgebirge, Germany. J. Petrol. 40, 1613-1645.

GeIsLer, T. \& Schleicher, H. (2000): Improved U-Th-total $\mathrm{Pb}$ dating of zircons by electron microprobe using a simple new background modeling procedure and $\mathrm{Ca}$ as a chemical criterion of fluid-induced $\mathrm{U}-\mathrm{Th}-\mathrm{Pb}$ discordance in zircon. Chem. Geol. 163, 269-285.

Graham, I.J. \& Korsch, R.J. (1990): Age and provenance of granitoid clasts in Moeata Conglomerate, Kawhia Syncline, New Zealand. J. R. Soc. N. Z. 20, 25-39.

HARPER, C.T. \& LANDIS, C.A. (1967): K-Ar ages from regionally metamorphosed rocks, South Island, New Zealand, and some tectonic implications. Earth Planet. Sci. Lett. 2, 419-429.

IRELAND, T.R. \& GIBSON, G.M. (1998): SHRIMP monazite and zircon geochronology of high-grade metamorphism in New Zealand. J. Metamorph. Geol. 16, 149-167.

ITo, M., Suzuki, K. \& Yogo, S. (1997): Cambrian granulite to upper amphibolite facies metamorphism of post-797 Ma sediments in Madagascar. J. Earth Planet. Sci., Nagoya Univ. 44, 89- 102.

Jarosewich, E. \& BoAtner, L.A. (1991): Rare-earth element reference samples for electron microprobe analysis. Geostandards Newsletter 15, 397-399.

KAMP, P.J.J. \& TIPPETT, J.M. (1993): Dynamics of Pacific plate crust in the South Island (New Zealand) zone of oblique continent-continent convergence. J. Geophys. Res. B98, 16105-16118.

Kato, M., SuZuki, K. \& Yogo, S. (1997): CHIME ages of zircons in granitic gneiss and granite from Samilpo, south- 
eastern Democratic People's Republic of Korea. J. Earth Planet. Sci., Nagoya Univ. 44, 61-69.

Kimbrough, D.L., Tulloch, A.J., Coombs, D.S., Landis, C.A., Johnston, M.R. \& Mattinson, J.M. (1994a): Uranium-lead zircon ages from the Median Tectonic Zone, South Island, New Zealand. N.Z. J. Geol. Geophys. 37, 393419.

Geary, E., CoOmbs, D.S. \& Landis, C.A. (1993): Isotopic ages from the Nelson region of South Island, New Zealand: crustal structure and definition of the Median Tectonic Zone. Tectonophys. 225, 433-448.

\& RatTenbury, M.S. (1994b): Late Jurassic - Early Cretaceous metamorphic age of Fraser Complex migmatite, Westland, New Zealand. N.Z. J. Geol. Geophys. 37, 137-142.

King, R.P., Jamieson, B.S. \& Turnbull, I.M. (1975): Fjordland Complex. In Geological Map of New Zealand, Te Anau Downs, sheet D42AC and part of sheet D43 (1:50,000) (I.M. Turnbull, ed.). N.Z. Geol. Surv., 7-11.

KuCHA, H. (1980): Continuity in the monazite-huttonite series. Mineral. Mag. 43, 1031-1034.

Meldrum, A., Boatner, L.A., Weber, W.J. \& Ewing, R.C. (1998): Radiation damage in zircon and monazite. Geochim. Cosmochim. Acta 62, 2509-2520.

ZinKLE, S.J., WANG, ShI-XIN, WANG, LU-MIN \& EwING, R.C. (1999): Effects of dose rate and temperature on the crystalline-to-metamict transformation in the $\mathrm{ABO}_{4}$ orthosilicates. Can. Mineral. 37, 207-221.

Montel, J.-M., Foret, S., Veschambre, M., Nicollet, C. \& Provost, A. (1996): Electron microprobe dating of monazite. Chem. Geol. 131, 37-53.

Muir, R.J., Ireland, T.R., Weaver, S.D. \& Bradshaw, J.D. (1994): Ion microprobe U-Pb zircon geochronology of granitic magmatism in the Western Province of the South Island, New Zealand. Chem. Geol. 113, 171-189.

Pabst, A. \& Hutton, C.O. (1951): Huttonite, a new monoclinic thorium silicate, with an account on its occurrence, analysis, and properties. Am. Mineral. 36, 60-69.

Parslow, G.R., Brandstätter, F., Kurat, G. \& Thomas, D.J. (1985): Chemical ages and mobility of $U$ and $T h$ in anatectites of the Cree Lake zone, Saskatchewan. Can. Mineral. 23, 543-551.

Pouchou, J.-L. \& PichoIR, F. (1985): "PAP" $(\phi-\rho-z)$ procedure for improved quantitative microanalysis. In Microbeam Analysis (J.T. Armstrong, ed.). San Francisco Press, San Francisco, California (104-106).

Rhede, D., Wendt, I. \& Förster, H.-J. (1996): A three-dimensional method for calculating independent chemical U/ $\mathrm{Pb}$ - and $\mathrm{Th} / \mathrm{Pb}$-ages of accessory minerals. Chem. Geol. 130, 247-253.
RoEDER, P.L. (1985): Electron-microprobe analysis of minerals for rare-earth elements: use of calculated peak-overlap corrections. Can. Mineral. 23, 263-271.

Seydoux, A.-M. \& Montel, J.-M. (1997): Experimental determination of the thorite-huttonite phase transition. Terra Nova 9, Abstr. Suppl. No. 1, 421.

SHANNON, R.D. (1976): Revised effective ionic radii and systematic studies of interatomic distances in halides and chalcogenides. Acta Crystallogr. A32, 751-767.

Sircombe, K.N. \& KamP, P.J.J. (1998): The South Westland Basin: seismic stratigraphy, basin geometry and evolution of a foreland basin within the Southern Alps collision zone, New Zealand. Tectonophys. 300, 359-387.

SpeER, J.A. (1982): The actinide orthosilicates. In Orthosilicates (P.H. Ribbe, ed.). Rev. Mineral. 5, 113-135.

Steiger, R.H. \& JäGER, E. (1977): Subcommission on geochronology: convention on the use of decay constants in geo- and cosmochronology. Earth Planet Sci. Lett. 36, 359-362.

SUZUKI, K. \& ADACHI, M. (1991): Precambrian provenance and Silurian metamorphism of the Tsubonosawa paragneiss in the South Kitakami terrane, northeast Japan, revealed by the chemical $\mathrm{Th}-\mathrm{U}-$ total $\mathrm{Pb}$ isochron ages of monazite, zircon and xenotime. Geochem. J. 25, 357-376.

\& KaJIZUKA, I. (1994): Electron microprobe observations of $\mathrm{Pb}$ diffusion in metamorphosed detrital monazites. Earth Planet. Sci. Lett. 128, 391-405.

Tadesse, T., Suzuki, K. \& Hoshino, M. (1997): Chemical Th - U - total lead isochron age of zircon from the Mereb granite in northern Ethiopia. J. Earth Planet. Sci., Nagoya Univ. 44, 21-27.

TiPPETT, J.M. \& KAMP, P.J.J. (1993): Fission track analysis of the Late Cenozoic vertical kinematics of continental Pacific crust, South Island, New Zealand. J. Geophys. Res. B98, 16119-16148.

Tulloch, A.J. (1992): Petrology of the Sams Creek peralkaline granite dike, Takaka, New Zealand. N.Z. J. Geol. Geophys. 35, 193-200

Waight, T.E., Weaver, S.D., Muir, R.J., MaAs, R. \& Eby, G.N. (1998): The Hohonu Batholith in North Westland, New Zealand: granitoid compositions controlled by source $\mathrm{H}_{2} \mathrm{O}$ contents and generated during tectonic transition. Contrib. Mineral. Petrol. 130, 225-239.

YARDLEY, B.W.D. (1982): The early metamorphic history of the Haast schists and related rocks of New Zealand. Contrib. Mineral. Petrol. 81, 317-327.

Received November 19, 1999, revised manuscript accepted March 16, 2000 